\title{
THE ECONOMIC VALUE AND COST RECOVERY OF WATER IN THE EGYPTIAN IRRIGATED AGRICULTURE
}

\author{
ENAS MOH. ABBAS SALEH
}

\author{
Agricultural Economics Research Institute (AERI),ARC, enas abbas saleh@yahoo.com
}

(Manuscript received 7 March 2018)

\begin{abstract}
$\mathrm{T}$ his article provides estimates for on-farm irrigation costs paid by farmers and the imputed economic value of water for the main crops in the study sample and identifies the appropriate method for the Egyptian conditions, and measures the impact of irrigation water consumption, water savings and gross margin in Egypt. Data were collected from a formal survey for 80 farmers conducted in 2016/2017 to collect data on the farm budgets of the crops prevailing in Al Satamony Village located at Dakahlia Governorate (Belkas District). Residual method was employed to impute the economic value of water and an assessment of crop-based irrigation water cost recovery policy was made in terms of its impact on irrigation water consumption and gross margin. Besides, the study conducted an online opinion poll about the possibility to recover a part of the operation and maintenance (O\&M) costs of irrigation in Egypt and the irrigation cost recovery method relevant to the Egyptian case. The results from this study confirm the need for additional investments to improve the efficiency of the existing irrigation system whereas, such investments are regarded as public good putting more pressure on the national budget. However, Egyptian farmers do not pay for water used in their farms. They bear only the on-farm irrigation costs. Thus, the Government of Egypt (GoE) considered more direct methods of recovering costs from farmers in order to reduce the government's recurrent fiscal burden while improving the efficiency and sustainability of O\&M services. Rice and clover ranked first in terms of high shadow price of irrigation water, followed by sugar beet, wheat and maize whereas, sugar beet and clover gained the highest water productivity. The analysis showed that crop-based scheme is the irrigation cost recovery policy most relevant to the Egyptian case. Such policy achieves water saving of at least half a million cubic metres for the old lands of Dakahlia Governorate. However, farm gross margin decreases as the total on-farm irrigation costs based on the crop-based irrigation water tariff increase. This implied the importance of such policy that directly affect famers' behaviour towards reducing irrigation water consumption and slightly decreases farm gross margin, as well. To conclude, there is a need for sufficient farmer's access to knowledge and improving communication channels between farmers and skilled agricultural extension personnel about the harmful effect of over-irrigation, the recommended crop water requirements, the role of water user associations (WUAs), and water-saving management techniques before introducing the proposed irrigation cost recovery policy. Besides, a public
\end{abstract}




\begin{abstract}
awareness campaign on the need to recover a part of the O\&M irrigation costs is one of the key action needed before introducing the proposed irrigation cost recovery policy in order to sustain water supply and delivery system, upgrade poorly served areas, and ensure continued provision of services. Ensuring farmers acceptability for the cost recovery mechanism and the irrigation water tariff is clearly understood to represent no more than cost of services rendered should be put into consideration before introducing the such policy. Finally, introducing the proposed irrigation cost recovery policy in Egypt helps recovering part of O\&M costs, encourage efficient resource use, encourage efficient provision of irrigation service, and achieves equitable water distribution.
\end{abstract}

Key words: water; economic value; shadow price; cost recovery; agriculture; efficiency; Egypt.

\title{
1. INTRODUCTION
}

Egypt is characterized by arid climate with very limited rainfall (Gersfelt, 2007). According to (The World Bank, 2005), Egypt is so reliant on the Nile river system for sustaining the national economy. Egypt receives about $98 \%$ of its annual renewable water resources from the River Nile, originating outside its international borders (CAPMAS, 2016). This is the cornerstone for water policy and decision makers in the country.

Indeed, Egypt's water needs increase with the rapidly growing population, rising living standards, and the needs demanded by the industries and agriculture (The World Bank, 2005). A close look at (CAPMAS, 2016) reveals that the agricultural sector consumes more than $80 \%$ of the total water use. Besides, Egypt's water demands are in excess of its available water supplies (Bader, 2004). Alongside limited water resources available and allocation of water resources among different sectors, Egypt is faced by potential water scarcity due to increasing water demand (Yokwe, 2004).

In spite of water scarcity, water losses occur resulting from poor distribution and management of irrigation water. Conveyance and distribution networks and onfarm practices are major factors contributing to this situation. Based on (MALR, 2009), water conveyance efficiency is estimated at about $70 \%$, and the overall efficiency of irrigation is estimated at about $50 \%$.

Hence, efforts should be made to increase water use efficiency and reach equity in water allocation, as well. In this context, (Tsur, 2005) mentioned that the course of water policy left open to increase efficiency of water use. This highlights the importance of knowledge about water value that contributes to improving water-use efficiency through better allocation of water at farm level.

On the other hand, (ICARDA and AusAID, 2011) and (Gersfelt, 2007) revealed 
that the Egyptian irrigation system is highly complex with about $40,000 \mathrm{~km}$ of public canals (first "principal or main canals" and second level "branch canals"), 80,000 km of private third-level or tertiary canals "mesqas" and the on-farm irrigation canals or quaternary canals ditches "merwas", 18,000 km of public drains, 22,000 public water control structures, and 670 large public pumping stations for irrigation. The main canals take in fresh water from the River Nile, secondary canals from the main canals, and tertiary canals water from the secondary canals.

The Ministry of Water Resources and Irrigation (MWRI) is responsible for the entire irrigation and drainage systems above the mesqa level. Hence, investments, operation and maintenance (O\&M) and rehabilitation costs of irrigation and drainage infrastructure systems above the mesqa level have traditionally been borne by MWRI and MWRI does not charge farmers for irrigation water delivery, except for the pumping costs from the mesqa to the field (MWRI, 2005). The mesqas and merwas are owned (although not necessarily constructed) by the landowners, and they are responsible for O\&M of the mesqas, merwas and field drains so called "on-farm irrigation costs" (Tsur and Dinar, 1995) and (Molle and Berkoff, 2007). Furthermore, small farm size prevails in Egypt and the traditional method for irrigation is to divide the farmer's land into small basins, so that he can irrigate his plots adequately (Abuzeid, 1995).

According to (USAID, 1993), efficient O\&M for the irrigation system is essential to collect, store, and deliver water to users in the right quantities, to the right locations, and at the right times. Besides, generating enough funds is essential for the sustainability of this system. Based on (Abu-zeid, 1993), increasing the efficiency of the of this system by modernization and improved development needs additional investments.

However, significant investments in water supply, transfer, distribution, delivery, O\&M, drainage, and rehabilitation of irrigation infrastructure are regarded as public good and receive financing through the national budget and from donor support (The World Bank, 2005).

As a result, maintaining, managing, and operating the irrigation system is expensive, putting more pressure on the national budget. During the period (20122017), about LE 1.39 billion of the Egyptian government budget was allocated to irrigation and drainage infrastructure investments, in average (MPMAR, 2017). Achieving adequate funds to properly operate and maintain the irrigation system is another challenge.

Inability to obtain the desired level of funding through the competitive annual budget process, combined with the expectation that direct cost recovery would have a large 
potential for water conservation, have prompted MWRI to consider more direct methods of recovering costs from farmers (Bowen and Young, 1986).

Despite, the costs of water and its recovery is one of the determinant factors for water resources development in Egypt (MWRI, 2002), no direct charges paid for water services to agriculture in Egypt. However, farmers are responsible for maintaining the mesqas and a limited degree of cost recovery put a burden on farmers for infrastructural improvements including installation of drainage, improvements to mesqas (Perry, 1996).

According to (Molle and Berkoff, 2007), (Dinar and Saleth, 2005) and (Abuzeid, 2001), although the ideas can be traced back to earlier periods, 1992 marks a convenient turning point in the debate on cost recovery: in 1992, the argument that water should be treated purely as an economic good originated by the Fourth Dublin Principle. Besides, economic instruments and the economic value of natural resources further found legitimacy in the 1992 First Rio Principle, supporting the 'implementation of allocation decisions through demand management, cost recovery mechanisms and regulatory measures'. Moreover, the relationship between the cost of goods and their market price is well known in economics (Abu-zeid, 2002).

Since irrigation cost recovery is the basis for ensuring proper O\&M, Egypt is now in the process of lowering the O\&M costs through transferring some responsibilities to the water users and designing and operating the networks in such a way as to ensure their high efficiency and cost-effectiveness, as well (Abu-zeid, 2002). Besides, cost recovery policies have the potential to mitigate water scarcity. Because of its key role in managing water demand management and augmenting water supply, cost recovery is an important policy instrument for creating incentives to conserve and allocate water efficiently (Hamdy and Lacirignola, 2002).

These discussions shed light on our research questions; what is the economic value of irrigation water? and how irrigation water cost recovery affects water consumption, water savings and gross margin in Egypt?

Consequently, this study was undertaken to highlight basic concepts and terminology (e.g. irrigation water charge, fee, price and cost recovery, etc.), purposes of cost recovery, and give a historical background on Egypt's experience with cost recovery in irrigated agriculture, as well. Besides, this study aims at providing estimates for onfarm irrigation costs paid by farmers and the imputed economic value of water for the main crops in the study sample, investigating and comparing various methods for irrigation cost recovery, identifying the method that would be appropriate for the Egyptian conditions, and measuring the impact of irrigation water consumption, water savings and gross margin in Egypt. Finally, the study attempts to reach some 
recommendations for the future prospective of irrigation cost recovery application in Egypt.

In order to reach these objectives, the study is divided into three further sections. In the second section, the methodological framework is provided whereas, results and discussions are presented in the third section. The last section concludes with some remarks and recommendations on policy implications.

\section{METHODOLOGICAL FRAMEWORK}

\subsection{Basic concepts}

There are several opinions concerning the concepts and terminology of irrigation water charge, fee, price, and cost recovery. According to (Molle and Berkoff, 2007) and (Abu-zeid, 2002), water charge can be defined as an actual (financial) payment by users to access water and it should be considered as an additional tax or a fee that covers part of the expenses of modernization, O\&M of the irrigation network. It is equivalent to a tariff (a term commonly used in the domestic sector when differential rates are set). However, charge is a term disliked by some decision makers, who fear that it suggests that water - perceived as a gift of ALLAH - is taxed. In 1979, several Asian countries agreed to replace it with the term irrigation service fee (ISF). This is now often adopted, though it conflicts with the definition of a fee as an administrative payment (e.g. for the registration of a water right). Another concept commonly used is water price. This is preferably confined to the (economic) price that emerges in a market as the result of the actions of willing buyers and willing sellers, with no connotation of (financial) cost recovery. Since such markets are rare in the water sector, price is often used as a synonym for charge to indicate the administrative rate set by an agency to a user (Molle and Berkoff, 2007) and (Tiwari and Dinar, 2002). Morover, the economics of water cost recovery assumes a wellbehaved water demand when the price of water is set to equal its marginal value product (MVP), a profit-seeking user will demand a given quantity that is linked to that price and can be predicted by the regulator who sets prices (Dinar and Saleth, 2005). The economic cost of providing water as a natural resource might be much higher than the value of irrigation water as an agricultural input. In a normal (regular) market, the economic value of water resource is its opportunity cost, which is the value in its best alternative use (McCauley et al., 2002).

Besides, (Barakat, 2002) and (USAID, 1993) revealed that irrigation cost recovery can be defined as the process of directly or indirectly capturing and directing to public agencies some portion of revenue resulting from the Government of Egypt (GoE) actions to provide irrigation services. (Fragoso and Marques, 2013) highlighted 
three basic elements for establishing irrigation water cost recovery policy, namely water value, full water cost and water price. Water value is determined by the derived demand side for irrigation water. The full water cost is given by the derived supply side for the O\&M cost, capital cost, opportunity cost and costs of economic and environmental externalities for irrigation water. The full supply cost is defined as the sum of O\&M and capital costs. Water price is the amount set by the institutional sector to ensure cost recovery, equity and sustainability, and may or may not be subsidized (Fragoso and Marques, 2013).

\subsection{Purposes of cost recovery}

Cost recovery is one of many policy interventions to mitigate both quantity and quality dimensions of water scarcity and enhance efficient water use (Dinar and Saleth, 2005). Based on (USAID, 1993), (Barakat, 2002), (Bader, 2004), (Dinar and Saleth, 2005) and (Reddy, 2009), irrigation cost recovery has three distinct functions or roles or objectives that can identified as underlying the purpose of the service charges; namely economic, financial, and social. The economic function is to ensure that resources (e.g. water) are efficiently used by charging beneficiaries a price equivalent to the value that society places on the resources employed. The financial function is to recover the costs of the service provided. The social function is to foster the development of one economic sector (e.g. the agricultural sector) or region of the country by providing financial resources from elsewhere in the economy and under certain conditions, cost recovery could also promote equity objectives through sharing the net benefits among the users of irrigation system.

Moreover, (Abu-zeid, 2002) revealed that the sustainability of the water supply and delivery system to ensure continued provision of services is accomplished by generating enough funds to cover the administration, O\&M and replacement of water system facilities. The source of such funds could come entirely from the state budget, entirely from the direct water users or from some combination. However, if none comes from the direct water users there will be no incentive to conserve water and use it rationally. Besides, if the water charges for the sustainability of services are not sufficient to induce the desired level of water conservation, it will be necessary to impose an additional component of cost recovery assigned specifically to the water users. That additional charge should be sufficient to encourage water users to practice the desired level of conservation. Another purpose of cost recovery is to provide funding to mitigate or compensate for damage caused by the water use.

\subsection{Background on Egypt's experience with cost recovery in irrigated agriculture}

According to (McCauley et al., 2002), prior to the socialist period in Egypt's 
political history and construction of the High Aswan Dam (HAD), farmers were heavily involved in the management of irrigation and flood control systems. The HAD was constructed and an extensive system of canals and drains was developed to provide water for irrigation the year around. Later, responsibility for O\&M of canal and drain systems was taken over by the central government, and farmers were only responsible for maintaining the mesqas. Farmers never paid directly for irrigation water service while they previously were heavily taxed on their output.

Prior to the liberalization of the agricultural sector (before 1986), farmers were forced to grow government-mandated crops and sell them at prices well below the world prices. Most inputs (e.g. fuel, fertilizer, seeds, and water) were subsidized, the revenue from output "taxes" easily exceeded the cost of subsidies. Thus, farmers were contributing to the government's ability to maintain the irrigation system (McCauley et al., 2002). In the mid-1980s, control on crops were eliminated, the GoE guaranteed floor prices for some crops (e.g. rice and wheat), the GoE taxation was far less than the cost of remaining subsidies, and the tax burden on farmers was light and farm income per unit of land increased substantially (McCauley et al., 2002).

Subsidies on farming inputs continued with no service charge on the delivery of irrigation water (e.g. fuel and fertilizer). Farmers were also provided with subsidized irrigation and drainage system improvements. By contrast, farmers were lightly taxed with land tax at almost a negligible level. Therefore, it was recommended either to eliminate this tax or to increase it to make it more efficient. However, it was politically difficult to remove remaining subsidies, including the introduction of charges for the delivery of irrigation water.

According to (The World Bank, 2005), there are two means for financing the costs of O\&M and investment; either increasing users' contributions by the cost recovery system or reducing the costs by improving the efficiency of service delivery. Rather than introducing water service charges, the GoE transferred more irrigation O\&M responsibilities to the farmers themselves through decentralization and promoting the formation of Water User Associations (WUAs) at mesqa level and empowering Water Boards (WBs) to manage irrigation and drainage O\&M at the secondary-canal branch level (McCauley et al., 2002).

For the sake of reducing the government's recurrent fiscal burden while improving the efficiency and sustainability of O\&M services, the GoE initiated several programs to implement cost recovery mechanisms for irrigation services e.g. Irrigation Improvement Project (IIP), sub-surface drainage projects by the Egyptian Public Authority for Drainage Projects (EPADP) and sugarcane programme (Barakat, 2002). 
Considering irrigation improvement cost recovery, the GoE launched the IIP aiming at increasing water availability in mesqas, improving the mesqas by alternative designs, the establishment of WUAs for each improved mesqa, and the establishment of the Irrigation Advisory Service (IAS) as a permanent component of the MWRI. Mesqa improving costs consists of three components; namely the investment costs of the mesqa pumps (excluding interest) repaid by the members to the GoE over a period not exceeding five years; the investment costs of civil works e.g. mesqa remodelling, PVC pipes, lining (excluding interest) repaid by the members to the GoE not later than the end of the first year following completion of mesqa improvement over a period not more than twenty years without interest based on farmer's capacity to pay; and O\&M costs directly paid by the members to the WUAs (Barakat, 2002). The WUAs determine the mode of O\&M cost recovery, encouraging the base recovery on a proxy for the volume of water (e.g. according to the time of pumping) rather than on a per feddan basis since this would provide incentives for improved water use efficiency (Abu-zeid, 2001). As for sub-surface drainage cost recovery, the GoE launched the EPADP aiming at covering the entire old agricultural land in the Nile Delta and Valley. After finishing the installation of the national drainage system, EPADP continued to its O\&M in addition to rehabilitation and replacement of the old drainage systems. In this case, farmers repay on-farm investment costs, but with an extensive grace period (MWRI, 2002). The sugarcane programme aims at improving field water application efficiency and yields by land levelling coupled with using gated pipes. Repayment by farmers for these investments is also subject to a substantial grace period, amounting to a subsidy element (MWRI, 2005).

In new lands, farmers are responsible for investment costs for all infrastructures including downstream of the booster pumps that draw from distributary canals (serving areas of about 100-200 feddans). Such investment may either be undertaken independently at farmers' expenses or by the GoE with cost recovery according to the rules set out above. Therefore, the policy of the GoE with respect to capital cost recovery is to recover no charges above the delivery point (mesqa head in the old land, booster pump in the new land) and a proportion of the investment costs below the delivery point (mesqa head in the old land, booster pump in the new land) and proportion of the investment costs below delivery point (MWRI, 2002).

\subsection{Data source and analysis}

2.4.1. Region of the study: The study was conducted in Dakahlia Governorate located at East Nile Delta of Lower Egypt. The cultivated area and cropped area of Dakahlia Governorate respectively reached about 634 and 1282 thousand feddans 
during the period (2011-2015), contributing to about $7.14 \%$ and $8.25 \%$ of the total cultivated and cropped areas of Lower Egypt in that order (MALR, 2017).

2.4.2. Surveying procedure and data collection: Data were collected from a formal survey conducted in 2016/2017 to collect data on the farm budgets of the crops prevailing in the study area. A multi-stage stratified random sampling design was used in this study to make representative sample. In the first stage, the country was classified into three clusters based on the geographic location; Lower, middle and Upper Egypt. The distribution of the sample across these three clusters were determined based on the weight proportional importance of the total amounts of irrigation water consumed and total conveyance and distribution losses in the irrigation network. Based on (CAPMAS, 2017), Lower Egypt consumed about $60 \%$ of the total irrigation water consumption in Egypt and Lower Egypt contributed to about two thirds of the total conveyance and distribution losses in Egypt, as well. Therefore, Lower Egypt was selected for the study. Then, Lower Egypt was classified into clusters based on its governorates. The distribution of the sample across these clusters were determined based on the weight proportional importance of the total area cultivated by water thirsty crops (e.g. clover, rice and sugarcane). In the third stage, Dakahlia Governorate was selected to conduct the study since it ranked at the top list of the total area cultivated by water thirsty crops (MALR, 2017). Then, Dakahlia Governorate was classified into clusters based on its districts. The distribution of the sample across these clusters were determined based on the weight proportional importance of the total cultivated area and Belkas District was selected to conduct the study since it ranks first in terms of total cultivated area in Dakahlia Governorate with more than about 81 thousand feddans (IDSC, 2014). Within Belkas District, villages were classified based on the total area cultivated by water thirsty crops and Al Satamony Village was selected to conduct the study. Finally, 80 farmers were randomly selected to conduct the current study.

Besides, an online opinion poll (survey of opinion) about the possibility to recover a part of the O\&M irrigation costs in Egypt and the irrigation cost recovery method relevant to the Egyptian case was developed and conducted, drawing on a panel of scientsts, researchers and deceision makers who wishes to participate, rather than a scientific sample of the population.

\subsection{Analytical methods}

Descriptive statistics such as percentage was used to analyse the socioeconomic characteristics of the farmers and farms in the study area. Moreover, the "residual" method was used to derive the shadow price of water. Based on (Heady, 1952), the "residual" method is most commonly applied to shadow pricing irrigation 
water and other producers' goods. Broadly, it determines the contribution of each input to output in the production process. If appropriate prices can be assignedpresumably by market forces-to all production inputs but one, the remaining total value of product is imputed to the remaining or residual resource. Hence, (Heady, 1952) and (Turner et al., 2004), assume the data are used to estimate production function in which a single product denoted $Y$ is produced by: capital $(K)$, labor $(L)$, land $(R)$, and irrigation water $(W)$ :

$Y=f(K, L, R, W)$. (equation 1)

Equation (1) is then used to derive the marginal physical products of resources (MPPi), Since: $M P P_{i}=\delta Y / \delta i$.

where: $M P P_{i}$ : marginal physical product; $i$ : denotes resource.

Profit-maximizing producers are assumed to add productive inputs to the point that the value of marginal products $\left(\mathrm{VMP}_{\mathrm{i}}\right)$ are equal to the opportunity cost of the inputs. $T V P_{Y}=\left(V M P_{k} Q_{k}\right)+\left(V M P_{L} Q_{L}\right)+\left(V M P_{R} Q_{R}\right)+\left(V M P_{W} Q_{W}\right)$ (equation 2)

where: TVPr: total value of product $(\mathrm{LE} / \mathrm{kg}) ; \quad V M P_{i}$ : value of marginal product $\left(\mathrm{LE} / \mathrm{m}^{3}\right) ;$

$Q_{i}$ : quantity of resource $(\mathrm{kg} /$ feddan).

Since: $V M P_{i}=P_{Y} * M P P_{i}=P_{i}$

where: $P_{i}$ : price of resource $\left(\mathrm{LE} / \mathrm{m}^{3}\right)$.

Then: $P_{W} Q_{W}=T V P_{Y}-\left(P_{k} Q_{k}+P_{L} Q_{L}+P_{R} Q_{R}\right)$ (equation 3)

Assuming that all variables in (equation 3) are known except $\mathrm{P}_{\mathrm{w}}$, the expression can be solved for that unknown to impute the shadow price of water $\mathrm{Pw}^{*}$ as follows:

$P_{W}^{*}=\left[T V P_{Y}-\left(P_{K} Q_{K}+P_{L} Q_{L}+P_{R} Q_{R}\right)\right] \div Q_{W}$ (equation 4)

where: $P_{W^{*}}$ : the shadow price of water or the imputed value of water used in the production $\left(\mathrm{LE} / \mathrm{m}^{3}\right)$.

\section{RESULTS AND DISCUSSION}

\subsection{Characteristics of selected sample}

3.1.1. Farmer's characteristics: Table 1 revealed that old farmers are dominated in the study sample since about $88 \%$ of the respondents are older than 44 years. Besides, about $18 \%$ of them are illiterates and only $3 \%$ of them can hardly read and write. However, the rest got poor education as only $9 \%$ of them had primary and secondary education whereas, only $3 \%$ of them had university education. A good proportion of the respondents gained good farming experience since about $90 \%$ of them spent more than 19 years in farming activities.

3.1.2. Farm characteristics: From the results presented in Table 1, farms in the study sample are typically small with an average area of about 2.5 feddans and with 
about $42 \%$ of the farms being less than two feddans. About $38 \%$ and $20 \%$ of the sample respondents respectively cultivate about 2-4 and more than four feddans. Moreover, wheat, clover and sugar beet tend to be dominant in the study area in winter whereas, rice and maize prevail in the summer season. Wheat+rice and wheat+maize crop rotations are more common in the sample. These results imply that the sample respondents get a lot out of their land.

Table 1. Farmer and Farm characteristics in the study sample.

\begin{tabular}{|c|c|c|c|c|c|}
\hline $\begin{array}{l}\text { Farmer } \\
\text { characteristics }\end{array}$ & Frequency & $\%$ & $\begin{array}{l}\text { Farm } \\
\text { characteristics }\end{array}$ & Frequency & $\%$ \\
\hline $\begin{array}{l}\text { Age: } \\
<45 \text { years }\end{array}$ & $\begin{array}{l}\mathbf{5 0} \\
6\end{array}$ & $\begin{array}{l}\mathbf{1 0 0} \\
12\end{array}$ & $\begin{array}{l}\text { Farm size (feddan): } \\
<2 \text { feddan }\end{array}$ & $\begin{array}{l}50 \\
21\end{array}$ & $\begin{array}{l}100 \\
42\end{array}$ \\
\hline $45-55$ years & 22 & 44 & $2-4$ feddan & 19 & 38 \\
\hline$>55$ years & 22 & 44 & $>4$ feddan & 10 & 20 \\
\hline $\begin{array}{l}\text { Education: } \\
\text { Illiterate } \\
\text { Can read and write } \\
\text { Primary } \\
\text { Secondary } \\
\text { University graduates } \\
\end{array}$ & \begin{tabular}{|l|}
$\mathbf{5 0}$ \\
26 \\
5 \\
2 \\
12 \\
5 \\
\end{tabular} & \begin{tabular}{|l|}
$\mathbf{1 0 0}$ \\
18 \\
3 \\
1 \\
8 \\
3 \\
\end{tabular} & $\begin{array}{l}\text { Cultivated crops: } \\
\text { Wheat } \\
\text { Clover } \\
\text { Sugar beet } \\
\text { Rice } \\
\text { Maize } \\
\end{array}$ & $\begin{array}{l}\mathbf{1 6 8} \\
50 \\
26 \\
25 \\
40 \\
27 \\
\end{array}$ & $\begin{array}{l}\mathbf{1 0 0} \\
30 \\
15 \\
15 \\
24 \\
16 \\
\end{array}$ \\
\hline $\begin{array}{l}\text { Farming experience: } \\
<20 \text { years } \\
20-30 \text { years } \\
>30 \text { years }\end{array}$ & \begin{tabular}{|l|}
$\mathbf{5 0}$ \\
5 \\
31 \\
14 \\
\end{tabular} & $\begin{array}{l}100 \\
10 \\
62 \\
28 \\
\end{array}$ & & & \\
\hline
\end{tabular}

Source: The results of the survey 2016/2017.

3.1.3. Water source and irrigation methods: The River Nile is the main source of irrigation, providing the study farms with more than $97 \%$ of water. Nile water is delivered to the study area through Al Satamony Canal, which receives its water from Bahr Shebin. Groundwater and mixed water are reliable sources used to cover water shortage during summer months. Surface irrigation method is dominant in the study area.

\subsection{Costs of irrigation:}

3.2.1. Costs of irrigation water delivery: According to ( $A O A D, 2006)$ and (Malik et al., 2014), the full costs of irrigation water supply consist of capital costs, O\&M and administration costs, and environmental externalities. The capital costs are one-time lump investments incurred over a short-time period in infrastructure building, replacement and rehabilitation (e.g. constructing storages, dams and conveyance systems) whereas, the O\&M and administration costs are incurred on a regular basis (often measured on an annual basis) in keeping the system in good working order and in appropriately managing the water available in the system in the most efficient way. Moreover, environmental externalities are the costs determined based upon the damages caused (e.g. additional costs of treatment to return the water to its original quality). Most countries aim to recover at least some part of the O\&M and administration costs only as "partial cost recovery" (e.g. Tunisia, Jordan, Argentina and Pakistan). However, some governments recover O\&M plus either fully or partly 
capital costs of irrigation water supply from the users (e.g. Morocco, Syria, Italy, Turkey and India).

Based on (Fragoso and Marques, 2013) and (Tsur and Dinar, 1995), the costs of irrigation water delivery consist of fixed and variable costs. The former consists of capital O\&M and includes taxes, insurance, interest on investment (the opportunity interest cost of investing in a water lifting system is the rate of return capital would earn in its next best alternative), permanent labour (e.g. pump guard), costs of wearout depreciation, some fixed O\&M for administration and rehabilitation (Wahby, H.; Quenemoen, G.; Helal, 1984). The latter is directly associated with processing and delivering the water to end users and water quantity supplied (the amount of time the system is operated), and usually includes the costs of energy for pumping and pressurization (diesel or electricity), grease, oil, repairs, temporary labour (e.g. pump operator), and O\&M expenses for cleaning of mesqas, merwas and drains. The variable cost depends on the amount of water delivered, while the fixed cost does not. In most countries (as in Egypt), the fixed cost is heavily subsidized (Tsur and Dinar, 1995).

\subsubsection{Estimation of farmer's (on-farm) irrigation costs for the main crops in}

the study sample: As mentioned before, Egyptian farmers do not pay for water used in their farms. Therefore, they bear only the on-farm irrigation costs e.g. cost of pumping energy (diesel), lubricants (grease \& oil), labour (pump operator), and irrigation pump maintenance. Besides, farmers are responsible for O\&M costs within tertiary - watercourse - command attached to their fields; mesqas and merwas, whereas MWRI pays O\&M costs for large mesqas.

It is evident from the results of Table 2 that rice and clover (water thirsty crops) ranked first in terms of total (on-farm) irrigation costs respectively reaching about LE 1032 and 833, followed by maize, sugar beet, and wheat with LE 825, 615, and 604 in that order. Moreover, rice and clover consumed the largest amount of fuel, with diesel costs of about LE 562 and 386, respectively. This was corresponded to increased water application for both crops. The cost of diesel, grease \& oil, and pump operator for rice constitute about $54.5 \%, 10 \%$, and $8 \%$ in that order. Furthermore, the cost of diesel, grease $\&$ oil, and pump operator for wheat contribute respectively to about $46 \%, 13 \%$, and $20 \%$ of the total (on-farm) irrigation costs. Besides, the cost of irrigation pump maintenance and repairs reflects normal replacement of filters representing about $21 \%, 26 \%, 19 \%, 27.5 \%$, and $28 \%$ for wheat, clover, sugar beet, rice, and maize, respectively. 
Table 2. Farmer's (on-farm) irrigation costs for the main crops in the whole study sample (LE).

\begin{tabular}{|l|l|l|l|l|l|l|l|l|l|}
\hline Crop & $\begin{array}{l}\text { Cost of } \\
\text { pumping } \\
\text { energy } \\
\text { (diesel) }\end{array}$ & $\%$ & $\begin{array}{l}\text { Cost of } \\
\text { lubricants } \\
\text { (grease \& } \\
\text { oil) }\end{array}$ & $\%$ & $\begin{array}{l}\text { Cost of labor } \\
\text { (pump } \\
\text { operator) }\end{array}$ & $\%$ & $\begin{array}{l}\text { Cost of } \\
\text { pump } \\
\text { maintenance }\end{array}$ & $\begin{array}{l}\text { Total (on- } \\
\text { farm) } \\
\text { irrigation } \\
\text { costs }\end{array}$ \\
\hline Wheat & 278 & 46.00 & 79 & 13.14 & 122 & 20.21 & 125 & 20.66 & $\mathbf{6 0 4}$ \\
Clover & 386 & 46.34 & 104 & 12.42 & 125 & 15.02 & 218 & 26.22 & $\mathbf{8 3 3}$ \\
Sugar beet & 296 & 48.14 & 74 & 12.03 & 126 & 20.50 & 119 & 19.33 & $\mathbf{6 1 5}$ \\
Rice & 562 & 54.43 & 106 & 10.24 & 81 & 7.88 & 283 & 27.45 & $\mathbf{1 0 3 2}$ \\
Maize & 391 & 47.40 & 90 & 10.92 & 110 & 13.38 & 233 & 28.30 & $\mathbf{8 2 5}$ \\
\hline
\end{tabular}

Source: The results of the survey 2016/2017.

\subsection{Estimation of the imputed economic value of water for the main crops} in the study sample

(McCauley et al., 2002) stated that the marginal return to water in agriculture is the additional value of output (crop production) generated by an additional one cubic meter of water. It determines the demand for irrigation water. For a certain agricultural activity (crop), the demand for water as an agricultural production factor is derived from the demand for this crop. The value of marginal product of this crop is the demand price of water at different quantity of water applied per feddan. However, under existing water policies in Egypt, such derived price of irrigation water, if estimated, would represent the shadow price of water, rather than a market price, because the farmers do not pay for irrigation water as a scarce natural resource. Hence, the marginal return to irrigation water (as a shadow demand price of water for agriculture) is the incremental crop yield generated by the last added cubic meter of irrigation water multiplied by the crop price. Therefore, the residual method was applied to estimate the shadow price of water for wheat, clover, sugar beet, rice and maize as shown in Table 3. 
Table 3. Estimation of the economic value of water for the main crops in the whole study sample.

\begin{tabular}{|c|c|c|c|}
\hline Crop & Notation & Variable & Value \\
\hline 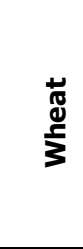 & $\begin{array}{l}\operatorname{MPP}_{W}^{(1)} \\
\boldsymbol{P}_{Y} \\
\operatorname{VMP}_{W}^{(2)} \\
\operatorname{AP}_{W}^{(3)} \\
\varepsilon_{W}^{(4)}\end{array}$ & $\begin{array}{l}\text { Marginal physical product of irrigation water }\left(\mathrm{kg} / \mathrm{m}^{3}\right) \\
\text { Farm-gate price of output ( } \mathrm{LE} / \mathrm{kg}) \\
\text { Value of marginal product (or shadow price) of irrigation water } \\
\left(\mathrm{LE} / \mathrm{m}^{3}\right) \\
\text { Average physical product of irrigation water }\left(\mathrm{kg} / \mathrm{m}^{3}\right) \\
\text { Elasticity of production for irrigation water }\end{array}$ & $\begin{array}{l}-0.35 \\
3.73 \\
1.32 \\
1.62 \\
-0.22\end{array}$ \\
\hline $\begin{array}{l}\text { ঠे } \\
\text { ठ0 }\end{array}$ & $\begin{array}{l}\operatorname{MPP}_{W}^{(1)} \\
\boldsymbol{P}_{Y} \\
\operatorname{VMP}_{W}^{(2)} \\
\operatorname{AP}_{W}^{(3)} \\
\varepsilon_{W}^{(4)}\end{array}$ & $\begin{array}{l}\text { Marginal physical product of irrigation water }\left(\mathrm{kg} / \mathrm{m}^{3}\right) \\
\text { Farm-gate price of output }(\mathrm{LE} / \mathrm{kg}) \\
\text { Value of marginal product (or shadow price) of irrigation water } \\
\left(\mathrm{LE} / \mathrm{m}^{3}\right) \\
\text { Average physical product of irrigation water }\left(\mathrm{kg} / \mathrm{m}^{3}\right) \\
\text { Elasticity of production for irrigation water }\end{array}$ & $\begin{array}{l}3.89 \\
0.43 \\
1.67 \\
8.17 \\
0.48 \\
\end{array}$ \\
\hline 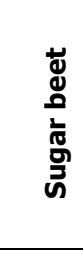 & $\begin{array}{l}\operatorname{MPP}_{w}^{(1)} \\
\boldsymbol{P Y}_{Y} \\
\operatorname{VMP}_{w}^{(2)} \\
\operatorname{AP}_{w}^{(3)} \\
\varepsilon_{w^{(4)}}\end{array}$ & $\begin{array}{l}\text { Marginal physical product of irrigation water }\left(\mathrm{kg} / \mathrm{m}^{3}\right) \\
\text { Farm-gate price of output }(\mathrm{LE} / \mathrm{kg}) \\
\text { Value of marginal product (or shadow price) of irrigation water } \\
\left(\mathrm{LE} / \mathrm{m}^{3}\right) \\
\text { Average physical product of irrigation water }\left(\mathrm{kg} / \mathrm{m}^{3}\right) \\
\text { Elasticity of production for irrigation water }\end{array}$ & $\begin{array}{l}2.81 \\
0.52 \\
1.47 \\
9.71 \\
0.29\end{array}$ \\
\hline$\frac{\tilde{u}}{\alpha}$ & $\begin{array}{l}\operatorname{MPP}_{W}^{(1)} \\
\boldsymbol{P}_{Y} \\
\operatorname{MMP}_{W}^{(2)} \\
\operatorname{AP}_{W}^{(3)} \\
\varepsilon_{W}^{(4)} \\
\end{array}$ & $\begin{array}{l}\text { Marginal physical product of irrigation water }\left(\mathrm{kg} / \mathrm{m}^{3}\right) \\
\text { Farm-gate price of output ( } \mathrm{LE} / \mathrm{kg}) \\
\text { Value of marginal product (or shadow price) of irrigation water } \\
\left(\mathrm{LE} / \mathrm{m}^{3}\right) \\
\text { Average physical product of irrigation water }\left(\mathrm{kg} / \mathrm{m}^{3}\right) \\
\text { Elasticity of production for irrigation water }\end{array}$ & $\begin{array}{l}0.48 \\
3.83 \\
1.84 \\
0.79 \\
0.61 \\
\end{array}$ \\
\hline$\frac{\mathbb{N}}{\frac{N}{\mathbf{N}}}$ & $\begin{array}{l}\operatorname{MPP}_{W}^{(1)} \\
P_{Y} \\
\operatorname{VMP}_{W}^{(2)} \\
\operatorname{AP}_{W}^{(3)} \\
\varepsilon_{W}^{(4)}\end{array}$ & $\begin{array}{l}\text { Marginal physical product of irrigation water }\left(\mathrm{kg} / \mathrm{m}^{3}\right) \\
\text { Farm-gate price of output }(\mathrm{LE} / \mathrm{kg}) \\
\text { Value of marginal product (or shadow price) of irrigation water } \\
\left(\mathrm{LE} / \mathrm{m}^{3}\right) \\
\text { Average physical product of irrigation water }\left(\mathrm{kg} / \mathrm{m}^{3}\right) \\
\text { Elasticity of production for irrigation water }\end{array}$ & $\begin{array}{l}0.14 \\
2.77 \\
\mathbf{0 . 3 8} \\
1.39 \\
0.10\end{array}$ \\
\hline
\end{tabular}

Source: The results of the survey 2016/2017.

The above analysis revealed that the shadow price of irrigation water for wheat, clover, sugar beet and rice respectively reached about LE 1.32, 1.67, 1.47 and 1.84 per one cubic metre. Moreover, the imputed value of irrigation water used in the production for maize reached about LE 0.38 per one cubic meter. This result was consistent with (Abd El-Halim, 2015), who calculated it as LE 0.25 per one cubic meter. Besides, a close look at the same Table reveals that clover and sugar beet ranked first in terms of irrigation water productivity whereas, rice reached the least irrigation water productivity.

\subsection{Irrigation water cost recovery methods}

According to (Dinar and Saleth, 2005), cost recovery methods of irrigation water consists of volumetric, non-volumetric, and market-based cost recovery methods. Volumetric mechanisms are based on measuring or assessing the actual 
amounts of water consumed, including: price setting, monitoring volumes, and fee collection. Non-volumetric methods are based on measurement of surrogate measures such as output, input, area, or land values. It is likely that non-volumetric methods face inadequate information concerning actual consumption volumes. This is also a concern with volumetric methods, although to a lesser extent. The recently exercised market-based mechanisms for allocating and setting prices for irrigation water necessitate well-defined water rights to determine the irrigation water price. There are also combinations of these methods. In principle, there are two distinct groups of irrigation cost recovery methods in practice around the world: (1) administrative and (2) market-based methods. The administrative methods can also be grouped into volumetric and non-volumetric ones (as was indicated earlier), and combination of the two.

Besides, (McCauley et al., 2002) reported that the implementation costs associated with volumetric cost recovery are relatively high and require the central water authority or water user association to set the fee, monitor use, and collect revenue. Volumetric cost recovery is most feasible under demand-based or closed pipe irrigation systems. It is difficult under a rotation system and nearly impossible under a continuous flow system. Moreover, water markets can be distinguished on a spectrum from informal to formal. Water markets often are established informally when scarcity occurs. Typically, such informal trades consist of farmers making some economic arrangement for the trade or transfer of surplus ground or surface water for a period of time (often a crop season) to a neighbouring farm or town. For formal water markets to work there must be buyable and sellable water rights. Markets can provide a more flexible and efficient mechanism to allocate water than administrative means. Groundwater charges are sometimes applied in areas where the seepage of irrigation water into aquifers replenishes groundwater pumped by another party. The distributor of the irrigation water, which may be an individual or an irrigation association, may seek to recover some of the (downstream) benefits enjoyed by the groundwater user.

Based on (Tsur, 2005), the preferred cost recovery method is the one that yields the highest benefit, including transaction costs. In the absence of implementation costs, the volumetric method is efficient. With implementation costs, other methods may perform better. As the implementation costs associated with each cost recovery method vary widely from region to region, due to variations in climate, demography, social structure, water rights, water facilities, history and general economic conditions, the net benefit associated with each method will vary from region to region. Regarding water markets, it is expected that well-defined tradable 
rights would formalize and secure the existing water rights held by users, economize the transaction costs, and increase efficiency of water use by inducing users to internalize the full opportunity cost of water, determined by the market, as opposed to a price imposed administratively. Water projects, however, often involve a small number of participants, entail uncertainty (e.g., in rainfall and stream flows) and exhibit increasing returns to scale (e.g., large- scale water projects), and each of these factors leads to market failure. Thus, the scope for using water markets is rather limited.

Moreover, (Fragoso and Marques, 2013) showed that each of these water cost recovery schemes is associated with different levels of welfare and net benefits, and choice depends particularly on the implementation cost, which varies from region to region due to climate issues, demography, social structure, water rights, water facilities, history and economic conditions. The preferred cost recovery method should be the one that achieves the highest benefit. In the absence of implementation cost, volumetric methods are the most efficient.

Besides, (Abu-zeid, 2002) and (Barakat, 2002) reported that a viable cost recovery policy should have few or no negative impact in terms of distorting incentives and inequity of impact, be transparent in calculation and application, be administratively simple, and be politically and socially acceptable by the water users.

Table 4 provides a list of these methods and a short explanation of their characteristics and a comparison of the implementation aspects of the various cost recovery methods. 
Table 4. Comparison of irrigation water cost recovery schemes (efficiency/equity/implementation costs).

\begin{tabular}{|c|c|c|c|c|c|c|c|c|}
\hline \multicolumn{2}{|c|}{\begin{tabular}{|l|} 
Cost \\
recovery \\
scheme
\end{tabular}} & Operation principles & \begin{tabular}{|l|} 
Potential \\
efficiency
\end{tabular} & $\begin{array}{l}\text { Time } \\
\text { horizon of } \\
\text { efficiency }\end{array}$ & $\begin{array}{l}\text { Ability to } \\
\text { control } \\
\text { demand }\end{array}$ & Equity & Implementation & Characteristics \\
\hline \multirow{3}{*}{ 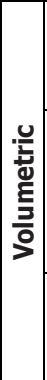 } & $\begin{array}{l}\text { Single- } \\
\text { rate }\end{array}$ & $\begin{array}{l}\text { Water is charged per volume consumed, including indirect calculation } \\
\text { based on measurement of minutes of known flow (from a reservoir) or } \\
\text { minutes of uncertain flow (proportions of a flow of a river); and a charge } \\
\text { for a given minimal volume to be paid for even if not consumed. }\end{array}$ & First-best & Short-run & Easy & $\begin{array}{l}\text { User-pays fairness } \\
\text { principle }\end{array}$ & Complicated & $\begin{array}{l}\text { Requires water use } \\
\text { monitoring }\end{array}$ \\
\hline & \begin{tabular}{|l|} 
Tiered \\
or \\
block- \\
rate or \\
block \\
tariff \\
\end{tabular} & $\begin{array}{l}\text { Water is charged per volume consumed. Once water meters are installed, } \\
\text { charges can be fixed for different levels of consumption. This is a multi-rate } \\
\text { volumetric method, in which water rates vary as the amount of water } \\
\text { consumed exceeds certain threshold values. Number of tiers could be } \\
\text { greater than } 2 \text {. Increasing block tariffs discourages excessive use. This is } \\
\text { applied in Jordan and Israel. }\end{array}$ & First-best & Short-run & $\begin{array}{l}\text { Relatively } \\
\text { easy }\end{array}$ & $\begin{array}{l}\text { Can be used to target } \\
\text { income groups for } \\
\text { subsidy or tax }\end{array}$ & $\begin{array}{l}\text { Relatively } \\
\text { complicated }\end{array}$ & $\begin{array}{l}\text { Requires water use } \\
\text { monitoring }\end{array}$ \\
\hline & \begin{tabular}{|l|} 
Two- \\
part \\
tariff
\end{tabular} & $\begin{array}{l}\text { Irrigators are charged a constant marginal price per unit of water used } \\
\text { (volumetric marginal cost recovery) and fixed annual charge (admission) } \\
\text { for the right to access water. Marginal cost recovery equates the price of a } \\
\text { unit of water with the marginal cost of supplying the last unit of water. }\end{array}$ & First-best & Long-run & $\begin{array}{l}\text { Relatively } \\
\text { easy }\end{array}$ & $\begin{array}{l}\text { Can be used to target } \\
\text { income groups for } \\
\text { subsidy or tax }\end{array}$ & $\begin{array}{l}\text { Relatively } \\
\text { complicated }\end{array}$ & $\begin{array}{l}\text { Requires water use } \\
\text { monitoring }\end{array}$ \\
\hline \multirow{3}{*}{ 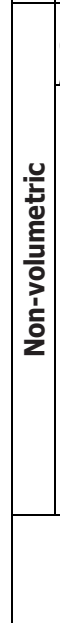 } & \begin{tabular}{|l} 
Per \\
output \\
/input
\end{tabular} & $\begin{array}{l}\text { Irrigators pay a certain water fee based on each unit of output produced or } \\
\text { on each unit of a certain input used other than water (e.g. fertilizers). }\end{array}$ & Second-best & Short-run & $\begin{array}{l}\text { Relatively } \\
\text { easy }\end{array}$ & $\begin{array}{l}\text { Can be used to target } \\
\text { income groups for } \\
\text { subsidy or tax }\end{array}$ & Less complicated & $\begin{array}{l}\text { Requires } \\
\text { input/output } \\
\text { monitoring }\end{array}$ \\
\hline & Per area & $\begin{array}{l}\text { Water is charged per irrigated area, depending on crop choice, the extent } \\
\text { of crop irrigated, the season of the year, irrigation method, etc. Charges } \\
\text { may be higher if there are storage works (investment) than for diversions } \\
\text { directly from streams. Pumped water is usually charged higher than water } \\
\text { delivered by gravity. In some cases, farmers are required to pay charges } \\
\text { for non-irrigated areas. There are three distinct types of charges; (1) flat } \\
\text { land charge: water is charged per lands actually both cultivable and served } \\
\text { by the irrigation system. It can be used when the volume is not measured } \\
\text { by meters, creating no incentive to conserve. This system is applied in } \\
\text { France, Greece, Spain, and Lebanon. (2) fixed charge: water is charged per } \\
\text { actual areas cropped in each of two or three seasons of the water year. A } \\
\text { fixed charge would be imposed on each crop receiving water during the } \\
\text { year. It is the easiest type to administer. (3) crop-based charge: water is } \\
\text { charged per required water use levels for each crop grown. It provides } \\
\text { some efficiency benefits, requiring greater administrative effort (reliable } \\
\text { records). This system is applied in Turkey and Italy. }\end{array}$ & Second-best & $\begin{array}{l}\text { Short- } \\
\text { run/long- } \\
\text { run }\end{array}$ & Hard & $\begin{array}{l}\text { Can be used to target } \\
\text { income groups for } \\
\text { subsidy or tax }\end{array}$ & Easy & $\begin{array}{l}\text { Requires data about } \\
\text { cropping patterns by } \\
\text { season }\end{array}$ \\
\hline & 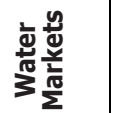 & $\begin{array}{l}\text { Irrigators sell/buy/rent water rights for an agreeable price for use at } \\
\text { present or in the future. }\end{array}$ & First-best & $\begin{array}{l}\text { Short- } \\
\text { run/long- } \\
\text { run }\end{array}$ & $\mathrm{N} / \mathrm{A}$ & $\begin{array}{l}\text { Depends on type of } \\
\text { market }\end{array}$ & $\begin{array}{l}\text { Difficult without } \\
\text { pre-established } \\
\text { institutions }\end{array}$ & $\begin{array}{l}\text { Requires developed } \\
\text { water institutions } \\
\text { and infrastructure }\end{array}$ \\
\hline
\end{tabular}

Source: Adapted from (Tsur and Dinar, 1995), (Kemper and Olson, 2000), (Abu-zeid, 2001), (Abu-zeid, 2002), (Hamdy, 2002), (Johansson et al., 2002), (Dinar and Saleth, 2005), (Tsur, 2005), (Reddy, 2009), and (Gallego-Ayala, 2012). 


\subsection{Irrigation cost recovery method relevant to the Egyptian case}

(USAID, 1993) revealed that identifying the goals of a cost recovery policy should be addressed before selecting a charging mechanism. If the policy goal is merely to find a different way to collect more revenues, then policymakers should select the simplest and most effective method which is palatable to farmers and the MWRI. If cost recovery is only part of a broader program to encourage economic efficiency, equity, and improved people management where the water delivery system and the farmers interact, then policymakers should consider more complex programs in which cost recovery is only one of many public purposes.

Several studies measured the impact of cost recovery alternatives on the agricultural sector. Such studies revealed that area-crop-based water charge instruments were as effective as volumetric charge based on the quantity of water delivered in Egypt (Perry, 1996) and (Bowen and Young, 1986). (Abu-zeid, 1993) recommended that cost recovery occur on a compound basis: the first is a unit area fee (fixed fee) and the second is an additional fee per water unit (variable fee). Moreover, (USAID, 1993) reported that two broad categories of cost recovery instruments may be considered in Egypt as a part of a broader program to improve economic efficiency, equity, and on-farm water management. The first category focuses on land area served and may be based on feddans of land irrigated annually or seasonally. Charging rates might be varied according to farm size. A further refinement would be to vary charges by crops, according to their water use. Flat land charges are relatively easy and inexpensive to administer but, they fail to penalize those who do not make the best economic use of the water in irrigation practices or choice of crops. The other category would be some sort of volumetric charge. Besides, (Bader, 2004) and (Bowen and Young, 1986) revealed that volumetric water charging mechanism is impractical in Egypt, because it needs a heavy capital inputs and administrative inputs. However, (ICARDA and AusAID, 2011) reported that land fragmentation is the main obstacle facing the application of volumetric water charging mechanism in Egypt since it requires the installation of millions of water meters and the employment of thousands of meter readers.

On the other hand, the results of the online opinion poll about the possibility to recover a part of the O\&M irrigation costs in Egypt revealed that about $90 \%$ of the participants were very satisfied with this policy whearas, the rest were dissatisfied with it. However, they highlighted the importance of using an acceptable cost recovery policy by farmers. Considering the main purposes of this policy, about $38 \%$ of the participants mentioned recovering part of O\&M costs, encouraging efficient resource use, encouraging efficient provision of irrigation service, and achieving 
equitable water distritribution whereas, about $32 \%$ of the participants focused only on recovering part of O\&M costs, and encouraging efficient provision of service. However, only $19 \%$, and $11 \%$ of participants respectively reported recovering part of O\&M costs, and recovering part of O\&M costs along with encouraging efficient resource use. Besides, about $51 \%$ of the participants reported crop-based scheme with higher rates for water-thirsty crops as a realistic irrigation cost recovery approach most relevant to Egypt. However, only $36 \%$ and $13 \%$ of the participants chose area-based and volumetric schemes (single-rate or increasing block tariffs). Besides, the participants identified the need to provide farmers with sufficient knowledge on the harmful effect of over-irrigation, the recommended crop water requirements, the role of WUAs, and water-saving management techniques, as well.

The participants reported that irrigation cost recovery mechanism starts gradually with big investors for favour of small farmers who are barely able to survive due to costly inputs and with cash crops in the areas where water-intensive crops are heavily cultivated in the beginning. They suggested collecting water tariff as an addon to agricultural land tax. This highlighted the importance of a public awareness campaign (e.g. on TV, radio, newspapers, social media, schools) as the most important first step-focusing on the main problems Egypt faces due to irrigation water losses, poor irrigation water conveyance efficiency, and water shortage. The campaign should also focus on the need to recover a part of the O\&M costs in order to sustain water supply and delivery system, upgrade poorly served areas, and ensure continued provision of services.

\subsection{The impact of irrigation cost recovery on water consumption, water savings and gross margin in Egypt}

Since the results of the online opinion poll reported crop-based scheme with higher rates for water-thirsty crops as the most relevant to Egypt, an assessment of this policy was made in terms of its impact on irrigation water consumption and gross margin. A tariff respectively of $10 \%, 15 \%$ and $20 \%$ was added to the economic value of water for the least water-consuming crops (wheat and sugar beet), moderate water-consuming crop (maize) and water-thirsty crops (clover and rice). Under this tariff, water consumption respectively reached about 1.86, 2.62, 2.14, 4.51 and 2.28 thousand $\mathrm{m}^{3} /$ feddan for wheat, clover, sugar beet, rice, and maize (Table 5 ). This allows achieving water saving of at least 492 million $\mathrm{m}^{3}$ in the old lands of Dakahlia Governorate. With respect to the total (on-farm) irrigation costs based on the proposed tariff, farm gross margin decreases as these costs increase. At this level of water tariff, the farm gross margin respectively reached about 8.62, 6.87, 8.94, 9.86 and 6.93 thousand LE/feddan for wheat, clover, sugar beet, rice and maize. This 
means a reduction of farm gross margin by about $2.8,11.3,3.4,14.4$ and 1.9 in that order.

Table 5. The impact of irrigation cost recovery on water consumption and gross margins for the main crops in the sample.

\begin{tabular}{|c|c|c|c|c|c|c|c|c|c|c|c|}
\hline & \multicolumn{2}{|c|}{$\begin{array}{l}\text { Economic value } \\
\text { of water "VMPw" } \\
\left(\mathrm{LE} / \mathrm{m}^{3}\right)\end{array}$} & \multicolumn{2}{|c|}{$\begin{array}{l}\text { Water } \\
\text { consumption } \\
\text { "Qw" } \\
\left(\mathrm{m}^{3} / \text { feddan }\right)\end{array}$} & \multirow{2}{*}{$\begin{array}{l}\text { Water } \\
\text { savings for } \\
\text { the whole } \\
\text { sample } \\
\text { ( } \mathrm{m}^{3} / \text { feddan) }\end{array}$} & \multicolumn{2}{|c|}{$\begin{array}{l}\text { Total (on-farm) } \\
\text { irrigation costs } \\
\left(\mathrm{LE} / \mathrm{m}^{3}\right)\end{array}$} & \multicolumn{2}{|c|}{$\begin{array}{l}\text { Gross margin } \\
\text { (LE/feddan) }\end{array}$} & \multicolumn{2}{|l|}{$\begin{array}{l}\text { Gross } \\
\text { decrease }\end{array}$} \\
\hline & Before & After & Before & After & & Before & After & Before & After & (LE/feddan) & $\%$ \\
\hline Wheat & 1.32 & 1.45 & 2046 & 1860 & 186 & 604 & 850 & 8863 & 8617 & 246 & 2.8 \\
\hline Clover & 1.67 & 2.00 & 3146 & 2622 & 524 & 833 & 1708 & 7747 & 6873 & 875 & 11.3 \\
\hline Sugar beet & 1.47 & 1.61 & 2356 & 2142 & 214 & 615 & 929 & 9250 & 8936 & 314 & 3.4 \\
\hline Rice & 1.84 & 2.21 & 5417 & 4514 & 903 & 1032 & 2692 & 11517 & 9856 & 1660 & 14.4 \\
\hline Maize & 0.38 & 0.44 & 2622 & 2280 & 342 & 825 & 956 & 7058 & 6927 & 131 & 1.9 \\
\hline
\end{tabular}

$Q_{W}=B_{W} *\left(Q_{Y} \div V M P_{W}\right) * P_{Y} \quad$ Gross margin $=$ Total revenue - Variable costs

Source: Table 3, (MALR, 2017), and The results of the survey 2016/2017.

The above analysis revealed that crop-based water cost recovery policy directly affects famers' behaviour towards reducing irrigation water consumption and it slightly decreases farm gross margin, as well.

\section{Concluding remarks, recommendations and policy implications}

The primary objectives of this study are to highlight basic concepts and purposes of irrigation water cost recovery and give a historical background on Egypt's experience with cost recovery in irrigated agriculture, as well. Besides, this study aims at providing estimates for on-farm irrigation costs paid by farmers and the imputed economic value of water for the main crops in the study sample, investigating and comparing various methods for irrigation cost recovery, identifying the appropriate method for the Egyptian conditions, and measuring the impact of irrigation water consumption, water savings and gross margin in Egypt.

To reach these objectives, a formal survey for 80 farmers was conducted in 2016/2017 to collect data on the farm budgets of the crops prevailing in Al Satamony Village located at Dakahlia Governorate (Belkas District). The study employed "residual" method to impute the economic value of water and an assessment of cropbased irrigation water cost recovery policy was made in terms of its impact on irrigation water consumption and gross margin. Besides, the study conducted an online opinion poll about the possibility to recover a part of the O\&M irrigation costs in Egypt and the most relevant scheme to the Egyptian case.

The results from our study confirm the need for additional investments to improve the efficiency of the irrigation system. Such investments are regarded as public good, putting more pressure on the national budget. However, Egyptian farmers do not pay for water used in their farms. They bear only the on-farm irrigation costs. Thus, the GoE considered more direct methods of recovering costs from farmers in order to 
reduce the government's fiscal burden while improving the efficiency and sustainability of O\&M services.

Our findings showed that wheat, clover and sugar beet are dominant in the study area in winter whereas, rice and maize prevail in the summer season. Water thirsty crops (rice and clover) ranked first in terms of total on-farm irrigation costs due to their increased water application and high consumption of fuel. This can be a positive result towards encouraging farmers to grow other crops rather than water thirsty ones, especially when farmers became keen with their water application and minimizing the costs of production they burden.

Our results brought out the fact that rice and clover ranked first in terms of high shadow price of irrigation water, followed by sugar beet, wheat and maize. Besides, sugar beet and clover gained the highest irrigation water productivity. Based on these results, the agricultural extension body should direct farmers towards the cultivation of high water productivity crops.

Based on our findings, recovering part of O\&M costs, encouraging efficient resource use, encouraging efficient provision of irrigation service, and achieving equitable water distribution were the main purposes of irrigation water cost recovery in Egypt. Therefore, a public awareness campaign on the need to recover such costs is one of the key action needed before introducing this proposed policy in order to sustain water supply and delivery system, upgrade poorly served areas, and ensure continued provision of services.

Moreover, our results highlighted the importance of ensuring farmers acceptability for the cost recovery mechanism and that the irrigation water tariff is clearly understood to represent no more than cost of services rendered. Thus, farmers should feel that they receive a reliable service for the tariff they pay for.

Besides, crop-based scheme is the irrigation cost recovery policy most relevant to the Egyptian case. Our results portray the positive impact of crop-based irrigation water tariff on achieving water saving of at least half a million cubic metres for the old lands of Dakahlia Governorate. However, farm gross margin decreases as the total onfarm irrigation costs based on the crop-based irrigation water tariff increase. This highlighted the importance of the crop-based irrigation water cost recovery policy that directly affect famers' behaviour towards reducing irrigation water consumption and slightly decreases farm gross margin, as well. This result was confirmed by (Abu-zeid, 2002) and (Barakat, 2002) showing that a viable cost recovery policy should have few or no negative impact in terms of distorting incentives and inequity of impact.

Our results showed the need to provide farmers with sufficient knowledge on the harmful effect of over-irrigation (e.g. on soil health, crop yield, and income), the 
recommended crop water requirements, and water-saving management techniques before introducing this proposed policy in Egypt. Therefore, there is a need for sufficient farmer's access to knowledge and improving communication channels between farmers and skilled agricultural extension personnel about such important issues. Besides, efforts should be directed towards generating awareness among the farmers regarding the importance of joining WUAs.

Furthermore, our results suggested that irrigation cost recovery mechanism starts gradually with big investors and cash crops in the areas where water-intensive crops are heavily cultivated. This highlighted the importance of a public awareness campaign as the most important first step-focusing on the main problems Egypt faces due to irrigation water losses, poor irrigation water conveyance efficiency, and water shortage. This campaign should also focus on the need to recover a part of the O\&M costs in order to sustain water supply and delivery system, upgrade poorly served areas, and ensure continued provision of services.

In this context, our results suggested collecting irrigation water tariffs as an add-on to agricultural land tax. Such mechanism can get benefits from the automated holdings and farmer's electronic smart card program recently launched by the GoE to provide a national database of agricultural holdings and financial services, ensure that subsidies reach the proper recipients for farmers, and develop the control and management model.

Finally, these recommendations are supported not only by our findings but also by the objectives of the National Agricultural Sustainable Development Strategy 2030 (MALR, 2009) and Water Resources Strategy 2050 (MWRI, 2010) targeting water rationalization, improvement of on-farm water management practices, decentralization of water management, and establishment of a mechanism to recover part of irrigation O\&M costs. Moreover, these recommendations are in perfect concordance with the objectives of the Sustainable Development Strategy: Egypt's Vision 2030 (MPMAR, 2016) targeting sustainable consumption patterns of water and natural resources through implementing a program for water rationalization in various sectors, especially agriculture and adopting policies that support water cost recovery. 


\section{REFERENCES}

1. Abd El-Halim, A.A., 2015. Water Saving under Fixed-furrow Surface Irrigation in Clay Soil of the Middle Nile Delta of Egypt, in: WIT Transactions on Ecology and the Environment. WIT Press, pp. 343-352. doi:10.2495/WS150291

2. Abu-zeid, M., 2002. Water Pricing in Irrigated Agriculture, Series A Mediterranean Seminars, No. 49, Water valuation and cost recovery mechanisms in the developing countries of the Mediterranean region, Options Méditerranéennes. Bari, Italy.

3. Abu-zeid, M., 2001. Water Pricing in Irrigated Agriculture. Int. J. Water Resour. Dev. Water Resour. Dev. 174, 527-538. doi:10.1080/07900620120094109

4. Abu-zeid, M., 1995. Major Policies and Programs for Irrigation Drainage and Water Resources Development in Egypt, Series B - Studies and Research, No. 9, Egyptian Agriculture Profile, Options Méditerranéennes. Bari, Italy.

5. Abu-zeid, M., 1993. Irrigation Cost Recovery in Developing Countries, Etat de I' agriculture en Méditerranée: Ressources en eau: développement et gestion dans les pays méditerranéens, Cahiers Options Méditerranéennes. Bari, Italy.

6. AOAD, 2006. Workshop Proceedings on Developing Irrigation Water Recovery Cost according to Local and International Changing Conditions. Arab Organization for Agricultural Development (AOAD), Tunisia, p. 155.

7. Bader, E., 2004. Mathematical Programming Models for Optimising Irrigation Water Management. Faculty of Agricultural of the Christian-Albrechts-University, Kiel.

8. Barakat, E., 2002. Cost Recovery for Irrigated Agriculture: Egyptian Experience, Series A - Mediterranean Seminars, No. 49, Water valuation and cost recovery mechanisms in the developing countries of the Mediterranean region, Options Méditerranéennes. Bari, Italy.

9. Bowen, R.L., Young, R.A., 1986. Appraising alternatives for allocating and cost recovery for irrigation water in Egypt. Agric. Econ. 1, 35-52. doi:10.1016/01695150(86)90005-8

10. CAPMAS, 2017. Annual Bulletins of Irrigation and Water Resources Statistics (2010-2015). Cairo, Egypt.

11. CAPMAS, 2016. The Statistical Year Book for 2015. Central Agency for Public Mobilization and Statistics (CAPMAS), Egypt.

12. Dinar, A., Saleth, M., 2005. Issues in Water Pricing Reforms: from Getting Correct Prices to Setting Appropriate Institutions. Int. Yearb. Environ. Resour. Econ. 2005/2006 A Surv. Curr. issues 1-51.

13. Fragoso, R., Marques, C., 2013. The Economic Impact of Alternative Water Pricing Policies in Alentejo Region (No. CEFAGE-UE Working Paper 2013/02). Portugal. 
14. Gallego-Ayala, J., 2012. Selecting Irrigation Water Pricing Alternatives Using a Multi-methodological Approach. Math. Comput. Model. 55, 861-883. doi:10.1016/j.mcm.2011.09.014

15. Gersfelt, B., 2007. Allocating Irrigation Water in Egypt, Cornell University, Ithaca, New York.

16. Hamdy, A., 2002. Water Pricing in Agricultural Sector Charging Mechanisms and Implementation, Series A - Mediterranean Seminars, No. 49, Water valuation and cost recovery mechanisms in the developing countries of the Mediterranean region, Options Méditerranéennes. Bari, Italy.

17. Hamdy, A., Lacirignola, C., 2002. Overcoming Water Scarcity and Quality Constraints: Water Pricing and Cost Recovery Potentialities, Series A Mediterranean Seminars, No. 49, Water valuation and cost recovery mechanisms in the developing countries of the Mediterranean region, Options Méditerranéennes. Bari, Italy.

18. Heady, E.O., 1952. Economics of Agricultural Production and Resource Use. Englewood Cliffs, NJ Prentice Hall, USA.

19. ICARDA and AusAID, 2011. Water and Agriculture in Egypt: Technical paper based on the Egypt-Australia-ICARDA Workshop on On-Farm Water-use Efficiency, Working Paper.

20. IDSC, 2014. Egypt's Description by Information, 11th Edition. Cabinet's Information and Decision Support Center (IDSC), Egypt.

21. Johansson, R.C., Tsur, Y., Roe, T.L., Doukkali, R., Dinar, A., 2002. Pricing Irrigation Water: A Review of Theory and Practice. Water Policy 4, 173-199. doi:10.1016/S1366-7017(02)00026-0

22. Malik, R.P.S., Prathapar, S. a., Marwah, M., 2014. Revitalizing Canal Irrigation Towards Improving Cost Recovery, IWMI Working Paper 160. Colombo, Sri Lanka. doi:10.5337/2014.211

23. MALR, 2017. Bulletins of Agricultural Statistics (2010-2015). Ministry of Agriculture \& Land Reclamation (MALR), Economic Affairs Sector, Central Department of Agrarian Economics \& Statistics, Cairo, Egypt.

24. MALR, 2009. Sustainable Agricultural Development Strategy towards 2030 (SADS). Ministry of Agriculture and Land Reclamation (MALR), Cairo, Egypt.

25. McCauley, D.S., Anderson, R., Bowen, R., Elassiouty, I., Mahdy, E., Soliman, I., Shehab, H., 2002. Economic Instruments for Improved Water Resources Management in Egypt: Summary Progress Report, Exploring the Potential of Applying Economic Instruments to Water Resources Management in Egypt. Cairo, Egypt.

26. Molle, F., Berkoff, J., 2007. Comprehensive Assessment of Water Management in Agriculture Series No. 4. Irrigation Water Pricing: The Gap Between Theory and Practice. CAB International. doi:10.1017/CBO9781107415324.004 
27. MPMAR, 2017. The National Socio-Economic Development Plan for Fiscal Year 2016/2017, Ministry of Planning and Follow-up and Administrative Reform (MPMAR). Cairo, Egypt.

28. MPMAR, 2016. Egypt Vision 2030 - Sustainable Development Strategy (SDS). Ministry of Planning, Monitoring and Administrative Reform (MPMAR), Cairo, Egypt.

29. MWRI, 2010. The Draft of the Development and Management of Water Resources Strategy 2050. Ministry of Irrigation and Water Resources (MWRI), Cairo, Egypt.

30. MWRI, 2005. National Water Resource Plan (NWRP) for Egypt-2017. Ministry of Irrigation and Water Resources (MWRI),Egypt.

31. MWRI, 2002. Adopted Measures to Face Major Challenges in the Egyptian Water Sector, in: Proceedings of the Hague 2nd World Water Forum 2000 to the Kyoto 3rd World Water Forum 2003. World Water Council (WWC).

32. Perry, C.J., 1996. Alternative Approaches to Cost Sharing for Water Service to Agriculture in Egypt, IWMI Research Report 2. Colombo, Sri Lanka. doi:http://dx.doi.org/10.3910/2009.015

33. Reddy, V.R., 2009. Water Pricing as a Demand Management Option: Potentials, Problems and Prospects.

34. The World Bank, 2005. Cost-effectiveness and Equity in Egypt's Water Sector Egypt and Public Expenditure Review (No. 3), World Bank Policy Notes. Washington, D.C., U.S.A.

35. Tiwari, D., Dinar, A., 2002. Role and Use of Economic Incentives in Irrigated Agriculture (No. 977 1), World Bank Technical Papers. Washington, D.C., U.S.A.

36. Tsur, Y., 2005. Economic Aspects of Irrigation Water Pricing. Can.Water Resour. Journal, Can. Water Resour.Assoc. 30(1),31-45.

37. Tsur, Y., Dinar, A., 1995. Efficiency and Equity Considerations in Pricing and Allocating Irrigation Water (No. 1460), World Bank Policy Research Working Paper. Washington, D.C., U.S.A.

38. Turner, K., Georgiou, S., Clark, R., Brouwer, R., 2004. Econmic Valuation of Water Resources in Agriculture, FAO Water Reports No. 27, FAO water reports 27. Rome, Italy.

39. USAID, 1993. Irrigation Water Cost Recovery in Egypt: Determination of Water Costs. Cairo, Egypt.

40. Wahby, H.; Quenemoen, G.; Helal, M., 1984. A Procedure for Evaluating the Cost of Lifting Water for Irrigation in Egypt.

41. Yokwe, S.C.B., 2004. Investigation of the Economics of Water as Used by Smallholder Irrigation Farmers in South Africa. Faculty of Natural and Agricultural Sciences, University of Pretoria. 


\title{
القيمة الاقتصادية لمياه الري واسترداد تكاليف إتاحة المياه \\ للزر اعة المروية المصرية الترية
}

\author{
إيناس محمد عباس صالح \\ - معهد بحوث الاقتصاد الزراعي - مركز البحوث الزراعية - جيزه
}

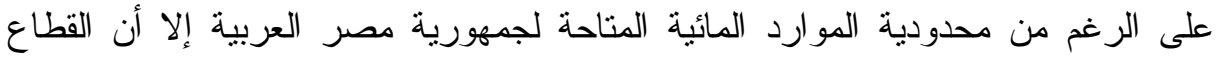
الزر اعي ما زال يستهلك ما يربو على 80\% من المياه سنوياً، وما زالت كفاءة استخدام مياه الري مئه

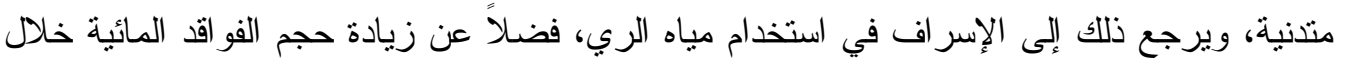

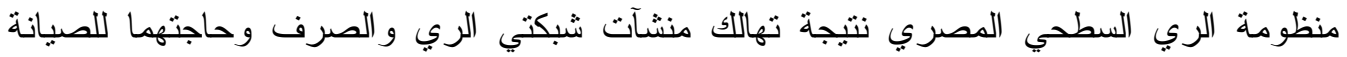
و إعادة التأهيل. وتتحمل الدولة كافة التكاليف الرأسمالية وهي تتمل تكاليف الاستهلاك (إهلاكك المعدات والآلات الرأسمالية) وفو ائد القروض، وتتحمل الدولة كذلك كافة تكاليف تشغيل وصيانة

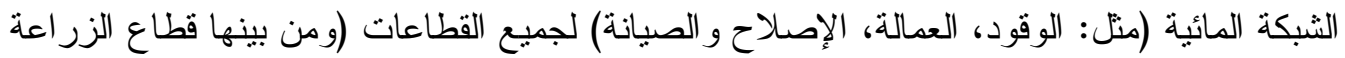

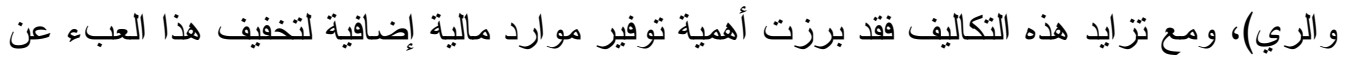

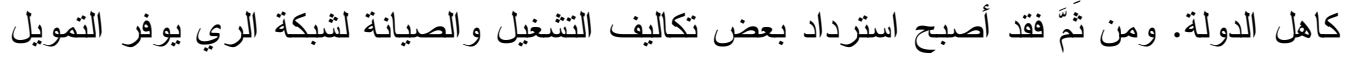

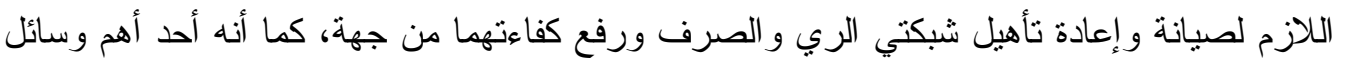

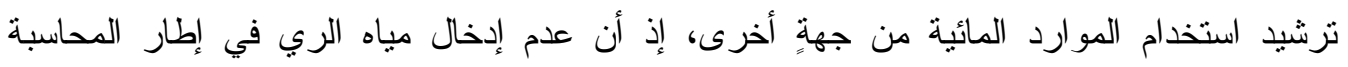
الاقتصادية أدى إلى الإسر اف في استخدامها.

وتحاول الدراسة الراهنة الإجابة عن تساؤلين هما: ماهي القيمة الاقتصادية لمياه الري؟

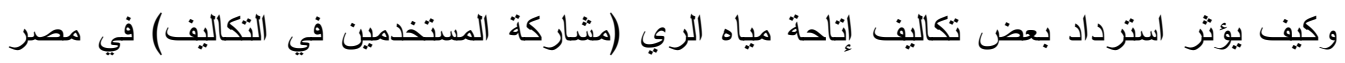

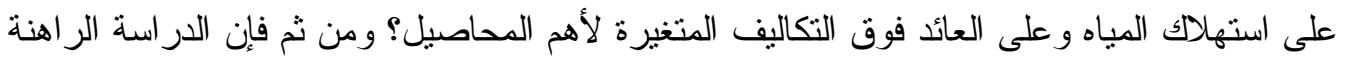
تستهدف تقدير تكاليف الري الحقلي لأهم المحاصيل بعينة الدراسة، وتقدير القيمة الاقتصادية لمياه

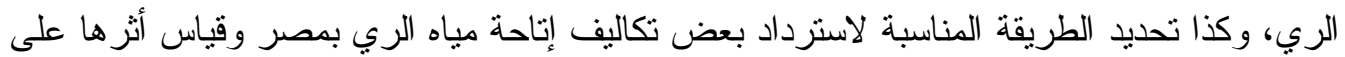

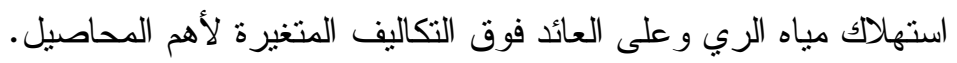

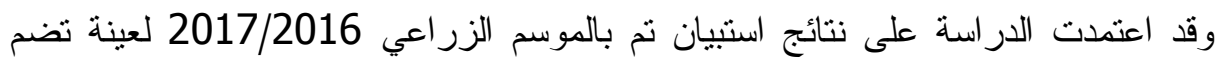

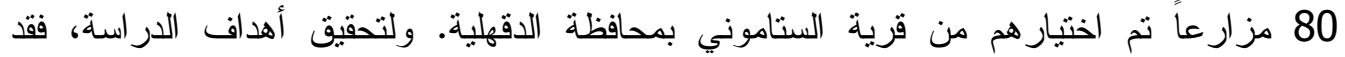
استخدمت طريقة البو اقي لتقدير القيمة الاقتصادية للمياه المستخدمة في إنتاج أهم المحاصيل بمنطقة

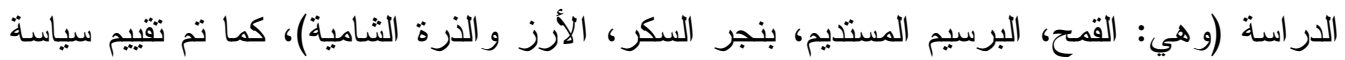

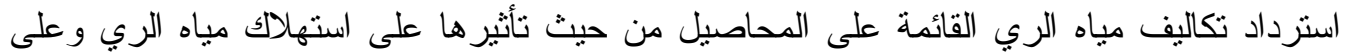

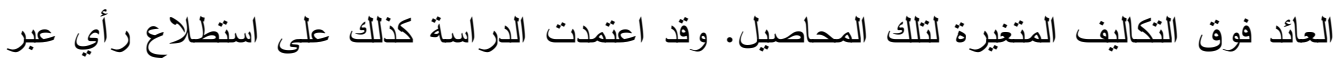
شبكة المعلومات الدولية حول إمكانية استرداد جزء من تكاليف التشغيل والصيانة لثبكة الرئي الرئي و الطريقة المناسبة لمصر . و أوضحت نتائج الدراسة الحاجة إلى توفير موارد مالية إضافية لصيانة وإعادة تأهيل ورفع كفاءة شبكتي الري والصرف وتخفيف هذا العبء عن ميزانية الدولة من خلال استرداد بعض تكائ تكاليف

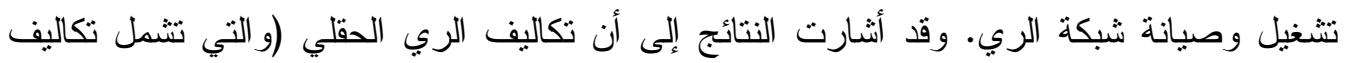

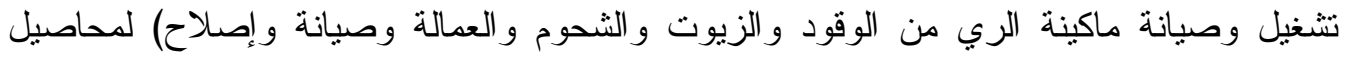


القمح، البرسيم المستديم، بنجر السكر، الأرز والذرة الثامية قد بلغت نحو 604، 833، 835، 615،

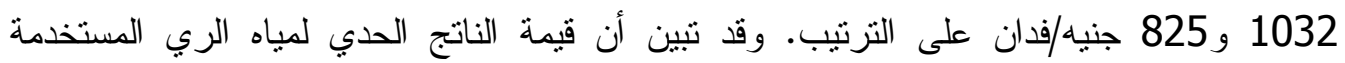

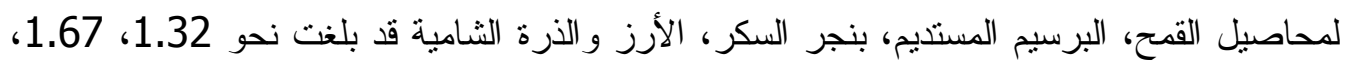

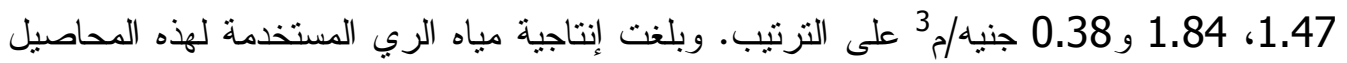

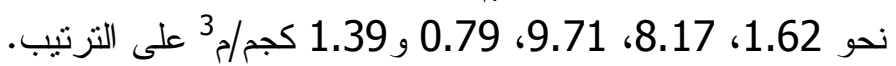

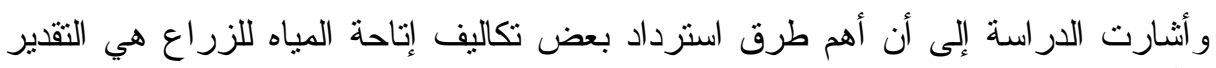

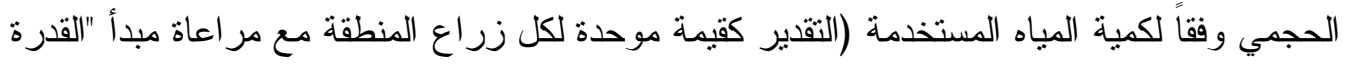

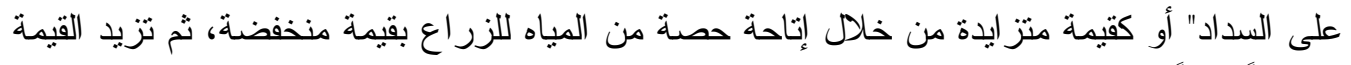

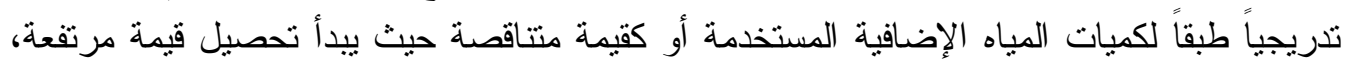
ثم تخفض القيمة بعد استهلاك كمية من المياه) أو بالتقدير غير الحجمي للاسترداد (كقيمة موحدة وفقاً لوحدة المساحة الأرضية أو المحصولية (جنيه/فدان) أو وفقاً لنوع المحصول الفيل على أساس كمية المياه

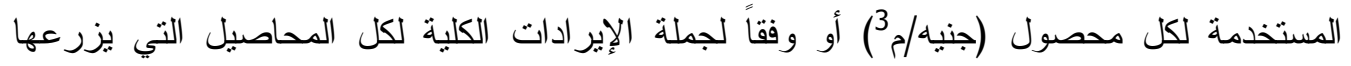
(المز ارع).

وقد تبين أن التقدير وفقاً لنوع المحصول هي أنسب الطرق لاسترداد بعض تكاليف إتاحة

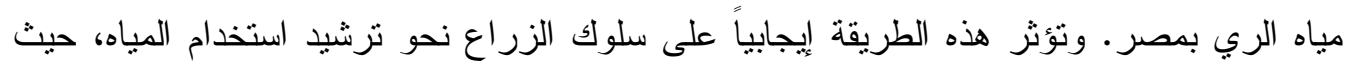

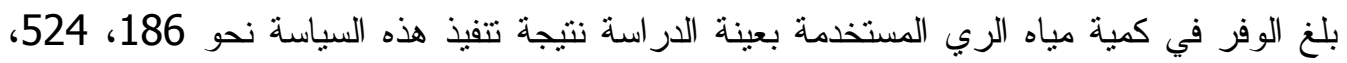

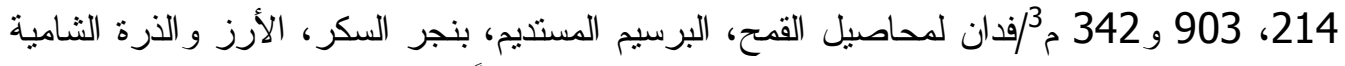

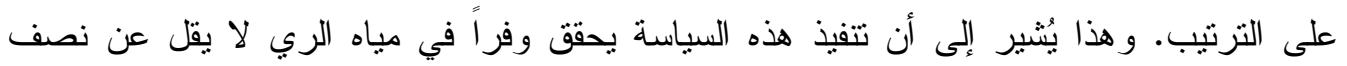

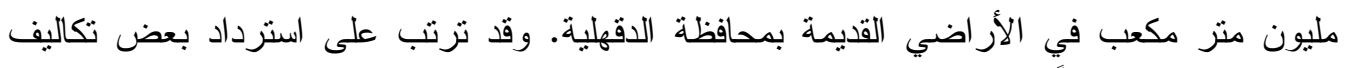

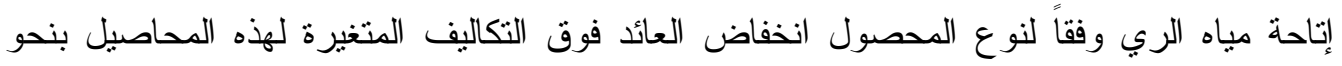

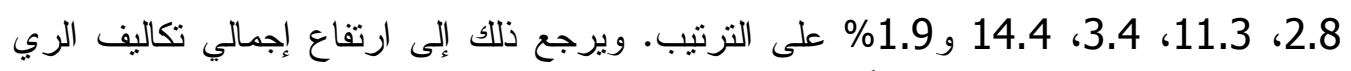
الحقلي بمقدار تعريفة مياه الري وفقاً لنوع المحصول.

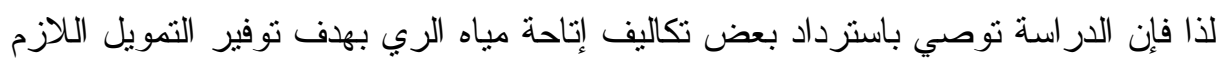

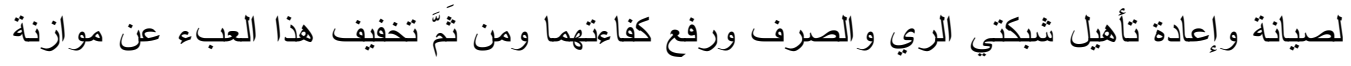

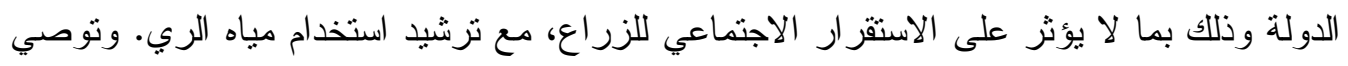

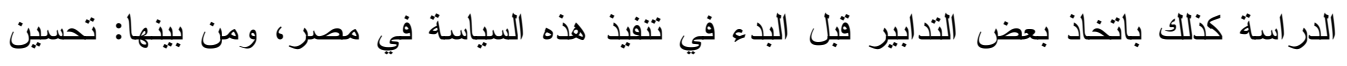

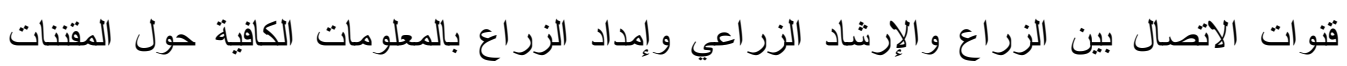

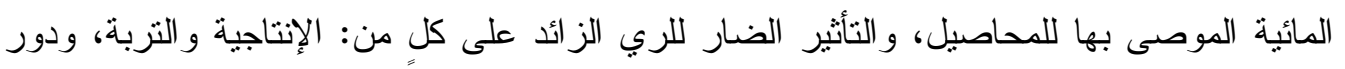

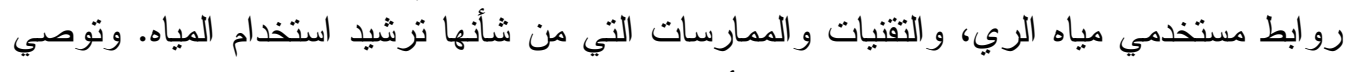

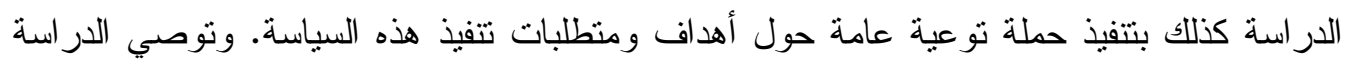
بالبدء التدريجي في تطبيق هذه السياسة على كبار المستثرين وعلى المحاصيل النقدية وعلى الثلى

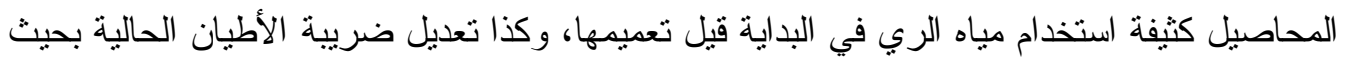

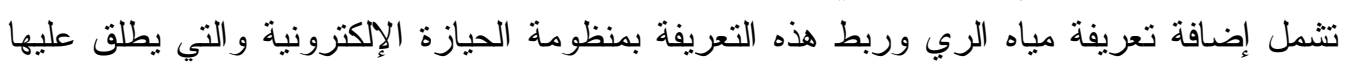

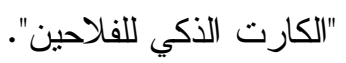


